\title{
Endangered anadromous lampreys in the southern Baltic Sea: spatial distribution, long-term trend, population status
}

\author{
Ralf Thiel ${ }^{1, *}$, Helmut M. Winkler ${ }^{2}$, Philip Riel $^{3}$, Renate Neumann' ${ }^{1}$, Tomas Gröhsler ${ }^{4}$, \\ Uwe Böttcher $^{4}$, Siegfried Spratte ${ }^{5}$, Uwe Hartmann ${ }^{5}$
}

${ }^{1}$ Biocenter Grindel and Zoological Museum, University of Hamburg, Martin-Luther-King-Platz 3, 20146 Hamburg, Germany

${ }^{2}$ Department of Biological Sciences, University of Rostock, Universitätsplatz 2, 18055 Rostock, Germany

${ }^{3}$ Zoological Institute and Museum, Ernst-Moritz-Arndt University Greifswald, Johann Sebastian Bach-Straße 11/12, 17487 Greifswald, Germany

${ }^{4}$ Institute of Baltic Sea Fisheries, Johann Heinrich von Thünen Institute, Federal Research Institute for Rural Areas, Forestry and Fisheries, Alter Hafen Süd 2, 18069 Rostock, Germany

${ }^{5}$ Office for Rural Areas, Department of Fishery, Wischhofstr. 1-3, 24148 Kiel, Germany

\begin{abstract}
We analysed $\sim 310$ records of river lampreys Lampetra fluviatilis (Linnaeus, 1758) ( 19977663 specimens) and 54 records of sea lampreys Petromyzon marinus Linnaeus, 1758 ( 86 specimens) for the southern parts of ICES Subdivisions 22 and 24 to 26 in the Baltic Sea covering the period 1649 to 2005. Most sea lamprey records came from Subdivisions 22 and 24. The majority of river lamprey records stem from Subdivisions 24 and 26. We found no distinct temporal trend for sea lamprey stock development. However, a long-term trend showing decreasing catches of river lamprey was detected, indicating a stock decrease of this species from 1887 to 1999. The largest numbers of lamprey (largely river lamprey but may include some sea lamprey as species were not distinguished in the past) were caught in the period 1890 to 1919. Approximately $82 \%$ of the total lamprey catch in our study area was made in Subdivision 26 . Roughly $65.3 \%$ of the mean annual yield of lampreys came from the lower Vistula River, the Vistula Lagoon and the Bay of Gdańsk. The river lamprey was mainly distributed in estuarine and coastal marine areas. Offshore records of sea lamprey were also rare. From 1990 to 2005, most river lamprey records and recorded individuals originated from the Szczecin Lagoon and its adjacent waters, demonstrating the present importance of these waters for their spawning migrations. Of 9 known river lamprey spawning sites, 5 were found in the Peene River system which flows into the Szczecin Lagoon. At present, no sea lamprey reproduction site is known from rivers of the German Baltic Sea area. A rebuilding programme is required for the river lamprey; this should definitely contain measures to restore lost spawning sites and the connectivities within the river systems where spawning populations still occur. Protected areas in estuarine waters with important lamprey migration routes may be an additional measure for the conservation of these anadromous species.
\end{abstract}

KEY WORDS: River lamprey $\cdot$ Lampetra fluviatilis $\cdot$ Sea lamprey $\cdot$ Petromyzon marinus $\cdot$ Baltic Sea • Past distribution $\cdot$ Commercial catch $\cdot$ Recent records

\section{INTRODUCTION}

Lampreys belong to the Agnatha - the most primitive and oldest group of all living vertebrates. Their fossils date back to the late Silurian and Devonian peri- ods 450 million years ago (Maitland 2003). Most recent lamprey species have an antitropical distribution and occur in the temperate and polar regions of both the northern and southern hemispheres (Kelly \& King 2001). An exception is the genus Tetrapleurodon 
which occurs in subtropical Mexico, but lives here at high altitude (Salewski 2003). In Eurasia and North America, lampreys are represented by the genera Lampetra, Petromyzon, Ichthyomyzon, Lethenteron, Eudontomyzon, Entosphenus and Caspiomyzon.

There are 39 recognised lamprey species worldwide (Potter 1980), 34 of which occur in the northern hemisphere (Krappe 2004). Four species belonging to the Petromyzontiformes are found in Germany (Freyhof 2002): the sea lamprey Petromyzon marinus Linnaeus, 1758, Vladykov's lamprey Eudontomyzon vladykovi Oliva \& Zanandrea, 1959, the river lamprey Lampetra fluviatilis (Linnaeus, 1758) and the brook lamprey Lampetra planeri (Bloch, 1784). However, due to little notable difference in chromosome number or in nuclear DNA content between the last 2 species (Schreiber \& Engelhorn 1998), it is still open to question whether the brook and the river lamprey are separate species (Igoe et al. 2004).

The river lamprey and the sea lamprey are the only 2 anadromous lamprey species living in German waters of the Baltic Sea, its estuaries and rivers (Spratte \& Hartmann 1998, Winkler et al. 2002). The river lamprey is found from southern Norway to the western Mediterranean; it also inhabits the coastal waters of the entire Baltic Sea and has been reported from Turkey (Erguven 1989). Anadromous sea lampreys occur on both sides of the North Atlantic Ocean. In the eastern North Atlantic, the species is found over much of the coastal area of western and northern Europe, from northern Norway to the western Mediterranean. It can also be found in eastern North America. In Europe, it is distributed as far north as Varanger Fjord in Norway $\left(70^{\circ} \mathrm{N}\right)$ and as far south as the western Mediterranean (Hubbs \& Potter 1971, Beamish 1980). It has recently been documented from the Aegean Sea (Economidis et al. 1999) and from Kola Bay (Reshetnikov 2003). Kelly \& King (2001) also reported several landlocked populations of sea lamprey in the North American Great Lakes, but no such populations are reported from Europe.

There is little information available on the distribution and status of the 2 anadromous lamprey species in European estuarine, coastal and offshore marine waters (e.g. in the Baltic Sea). On the other hand, it is known that populations of anadromous lampreys have declined dramatically in European inland waters, including those in Germany, since the mid-20th century (e.g. Kelly \& King 2001). Due to the decrease in their stocks and numbers in inland waters, both lamprey species are listed in: (1) Annex II of the European Union Habitats Directive as species of community interest, whose conservation requires the designation of Special Areas of Conservation (SACs); (2) Appendix III of the Bern Convention, which allows some exploitation of their populations; and (3) national Red Data Books throughout the southern Baltic Sea region, which often list these species as threatened. For instance, Fricke et al. (1996) group both species into the critically endangered category for the German Baltic Sea regions. The river lamprey is listed as vulnerable and the sea lamprey as endangered in the Red List of Poland (Głowaciński 2001, HELCOM 2007). In the Russian and Lithuanian Red Books, only the sea lamprey is listed in the endangered category, whereas the river lamprey is not listed as a threatened species (Anonymous 2001, HELCOM 2007). Although a trend towards recovery has recently been observed for the stocks of both species in several European waters (Kottelat \& Freyhof 2007), it is expected that the actual status of the populations of these species in Europe is still far from the historical situation.

Despite the review of Maitland (1980) which is important in compiling a baseline reference source on the ecology of European lamprey species, more detailed information is urgently needed about the status of Lampetra fluviatilis and Petromyzon marinus, especially in their estuarine, coastal and offshore marine habitats. For instance, for the southern Baltic Sea, there is no complete description of the past and present distribution and a detailed analysis of the temporal and spatial development of the commercial catches in these areas. Such studies would be important to define conservation requirements for anadromous lampreys in the southern Baltic Sea and as a basis to check whether rebuilding programmes for these species are necessary, and where and how they should be implemented.

The main objective of this paper is to analyse the distribution, trend, and status of the stocks of anadromous lamprey species within the southern parts of ICES Subdivisions 22 and 24 to 26 of the Baltic Sea (see Fig. 3). Specifically, this article aims to (1) analyse the temporal trends and spatial characteristics of the commercial catch of lampreys in the southern parts of ICES Subdivisions 22 and 24 to 26, (2) compile the historical records of lampreys from the same areas, and (3) summarise recent records of lampreys in German territorial waters and in waters of the German Exclusive Economic Zones (EEZ) and in the adjacent Polish waters of the Odra Estuary to analyse their current distribution.

\section{MATERIALS AND METHODS}

The status of anadromous sea and river lampreys in the southern Baltic Sea was analysed based on the following: (1) commercial catch statistics and relevant publications; (2) records from fish collections; 
(3) records from commercial and recreational fisheries; and (4) research fisheries. The data sources of records from different time periods and ICES subdivisions are presented in Tables $1 \& 2$. Analysis of available commercial catch data was performed for the territorial waters and EEZ waters of Germany, Poland, Lithuania and the Russian enclave of Kaliningrad within ICES Subdivisions 24 to 26 (see Fig. 3). The compilation of historical records until 1989 was made for ICES Subdivisions 22 and 24 to 26 . Analyses of recent records from 1990 until 2005 were focused on territorial waters and the EEZs of Germany and the adjacent Polish waters of the Odra Estuary within ICES Subdivisions 22 and 24. Records of the occurrence and distribution of sea and river lamprey were investigated for the time interval 1855-2005 and 1649-2005, respectively. Temporal trends and spatial characteristics of the commercial catch of lampreys in the southern Baltic Sea were analysed for the time period 1887-1999. All collected records of river and sea lamprey including information about locality and date of catch are summarised in Tables 1, 3 \& 4 and S1 \& S2 (Tables S1 and S2 are available as electronic supplementary material at www.intres.com/articles/suppl/n008p233_app.pdf). The distribution of historical and recent records summarising catches from the same localities during the same time periods are presented in Figs. 3 to 6. The geographic positions of records of lampreys were either obtained from available point positions of records, as midpoints of performed hauls, or were estimated for given locations using georeferenced maps. All geographic presentations of records of lampreys were conducted with GIS using the software ArcView GIS, version 3.3 (ESRI 2002).

Data from commercial catch statistics and publications. Publications containing original information about catch statistics of lampreys in the relevant areas were only available for Subdivisions 24 to 26. These data, together with information on the current location of spawning sites in German tributaries of the Baltic Sea, were assessed, selected and then compiled. For some annual yields during a few periods, yield data of river lampreys were only available either as weight units or in an old German unit of measure (Schock) which corresponds to 60 ind. In such cases, values used to convert units of weight into numbers or vice versa were obtained as mean values from these annual yields from the relevant periods which were given both in units of weight and numbers.

Data from fish collections. Fish collections and/or databases of museums and universities which we expected to contain lampreys from Subdivisions 22 and 24 to 26 of the southern Baltic Sea were analysed. In cases of uncertain identification, the specimens were re-identified. Fish collections and/or databases from 16 institutions were analysed. Sea and/or river lamprey records were obtained from the following 8 institutions, sorted here according to the total number of available records of these species:

- German Oceanographic Museum, Stralsund, Germany (GOMS, 7/5 records)

- Zoological Institute and Museum of the ErnstMoritz-Arndt-University Greifswald, Germany (ZMUG, 9/1 records)

- Museum of Natural History of the Humboldt University, Berlin, Germany (NHMB, 7/1 records)

- Zoological Museum of the Christian-AlbrechtsUniversity Kiel, Germany (ZMUK, 5/3 records)

- Zoological Institute and Museum of the University of Hamburg, Germany (ZMUH, 4/1 records)

- Zoological collection of the Department of Biology of the University of Rostock, Germany (ZSRO, 2/2 records)

- Zoological Museum of the University of Copenhagen, Denmark (ZMUC, 2/0 records)

- Museum of Natural History, Stuttgart, Germany (NHMS, 0/1 records).

Data from catch records of commercial and recreational fisheries. To ensure that commercial and recreational fishermen communicate actual catch records of lampreys, an information sheet containing drawings of the most important identification characteristics of the species was developed in 2003. This was then distributed to fishermen along the entire Baltic coast of Germany. Furthermore, cash awards were announced to be given to fishermen who communicate verified and accurate catches of lampreys. Overall, fishermen contributed to 5 records of sea lamprey and 56 records of river lamprey.

Data from research fisheries. The Institute of Baltic Sea Fisheries (vTI-OSF) contributed catch records of lampreys from Subdivisions 22 and 24 to 26 since 1991 based on data resulting from $\sim 3000$ hauls that were taken with bottom trawls. Some additional data from the vTI-OSF that originated from studies with bottom trawls in the region of Pommeranian Bay (Subdivision 24 ) and from surveys using pelagic trawls within the area of Subdivisions 22 and 24 to 25 were available for 1978 onwards. More details regarding the respective sampling regimes used are presented by Kloppmann et al. (2003).

The German Oceanographic Museum in Stralsund and the University of Rostock provided catch records of lampreys from research fisheries using bottom trawls, semi-pelagic trawls and shrimp trawls at 22 stations in the EEZ and territorial waters of Germany in the Baltic Sea region between the islands of Ruegen, Usedom and Bornholm during autumn 2003, and in spring, summer and autumn of 2004 and 2005. Overall, 
189 hauls were carried out during these surveys. More details of the construction of the trawls, the sampling procedures, catch efficiencies of the gears and details of the recorded lampreys are given in Thiel et al. (2004, 2005, 2007).

\section{RESULTS}

\section{Origin and quality of available records of lampreys}

A total of 310 records of river lampreys with at least 19977663 ind. and 54 records of sea lampreys with at least 86 ind. were obtained based on the analysis of all available data sources from 1649 to 2005 (see Tables 1, $3 \& 4$ and S1 \& S2).

For the time period considered, most records of sea lamprey (31 records, $57.4 \%$ ) originated from commercial catch statistics and publications (Table 1). Seventeen records $(31.5 \%)$ were obtained from the analysis of fish collections. Recent commercial and recreational fisheries supplied 9.3\% (5 records) of the total number of records, while research fishery provided $1.8 \%$ (1 record) of the records (Table 1).

Records of river lamprey also originated mainly from commercial catch statistics and publications (215 records, 69.4\%; Table 1). Commercial and recreational fisheries provided 56 records $(18.1 \%)$, whereas 33 records $(10.6 \%)$ stem from the analysis of fish collections; research fishery supplied 1.9\% (6 records) of the total (Table 1).

\section{Mean annual value, spatial characteristics and temporal trends of lamprey commercial catches in the southern parts of Subdivisions 24-26 of the Baltic Sea}

From the data sources studied, there is no information indicating that the sea lamprey has been used commercially in the considered area of the southern Baltic Sea. However, there is evidence that the river lamprey has been a commercial species in the southern Baltic Sea since the end of the 19th century, and probably even earlier.

Annual catches of lamprey (largely river lamprey but may include some sea lamprey as species were not distinguished in the past) showed high variations in the territorial waters and in the EEZs of the southern parts of Subdivisions 24 to 26 of the Baltic Sea (Fig. 1). The highest catches were obtained during the three $10 \mathrm{yr}$ periods from 1890 to 1919, when 44 430,38250 and $32794 \mathrm{~kg}$ of lampreys were caught annually (Table 2). Annual lamprey catches decreased significantly in subsequent years (Fig. 1). The mean annual catch of river lamprey ranged between 400 and $14814 \mathrm{~kg}$ within the 10 yr periods between 1950 and 1999 (Table 2), with the highest mean annual lamprey yield (14814 kg) obtained in the 1970 to 1979 period. No, or very minor, catches of lampreys were registered during the time periods 1919-1929, 1940-1954 and 1980-1984 (Fig. 1).

Approximately $81.6 \%$ of the total lamprey catch in the considered area of the southern Baltic Sea from 1887 to 1999 was obtained from Subdivision 26 (Table 2).

Table 1. Petromyzon marinus and Lampetra fluviatilis. Data sources of sea and river lamprey records for different time periods and ICES subdivisions (SD). Catch statistics refer to catch data in publications containing original information for the relevant areas. Collections refer to collections and/or databases of museums and universities which were expected to contain individuals of lampreys from Subdivisions 22 and 24 to 26 of the southern Baltic Sea. 'Recent commercial fisheries' refers to catch data obtained from commercial and recreational fisheries; 'Research fishery' refers to catch data obtained from fisheries research institutions. Gaps indicate no data available

\begin{tabular}{|c|c|c|c|c|c|c|c|c|c|c|c|}
\hline \multirow{2}{*}{ Time period } & \multirow{2}{*}{ Data source } & \multicolumn{5}{|c|}{ - Sea lamprey } & \multicolumn{5}{|c|}{ - River lamprey } \\
\hline & & SD 22 & 24 & 25 & 26 & Total & 22 & 24 & 25 & 26 & Total \\
\hline \multirow[t]{3}{*}{$1649-1939$} & Catch statistics & 1 & 4 & & & 5 & 7 & 49 & & 95 & 151 \\
\hline & Collections & 4 & 2 & & & 6 & 7 & 13 & 1 & 2 & 23 \\
\hline & Total & 5 & 6 & & & 11 & 14 & 62 & 1 & 97 & 174 \\
\hline \multirow[t]{3}{*}{$1940-1989$} & Catch statistics & 3 & 15 & & 2 & 20 & 1 & 13 & 3 & 41 & 58 \\
\hline & Collections & 1 & 8 & & & 9 & 1 & 7 & & & 8 \\
\hline & Total & 4 & 23 & & 2 & 29 & 2 & 20 & 3 & 41 & 66 \\
\hline \multirow[t]{5}{*}{$1990-2005$} & Catch statistics & 3 & 3 & & & 6 & & 6 & & & 6 \\
\hline & Collections & 1 & 1 & & & 2 & 1 & 1 & & & 2 \\
\hline & Recent commercial fisheries & 2 & 3 & & & 5 & & 56 & & & 56 \\
\hline & Research fishery & 1 & & & & 1 & & 6 & & & 6 \\
\hline & Total & 7 & 7 & & & 14 & 1 & 69 & & & 70 \\
\hline \multirow[t]{5}{*}{$1649-2005$} & Catch statistics & 7 & 22 & & 2 & 31 & 8 & 68 & 3 & 136 & 215 \\
\hline & Collections & 6 & 11 & & & 17 & 9 & 21 & 1 & 2 & 33 \\
\hline & Recent commercial fisheries & 2 & 3 & & & 5 & & 56 & & & 56 \\
\hline & Research fishery & 1 & & & & 1 & & 6 & & & 6 \\
\hline & Total & 16 & 36 & & 2 & 54 & 17 & 151 & 4 & 138 & 310 \\
\hline
\end{tabular}




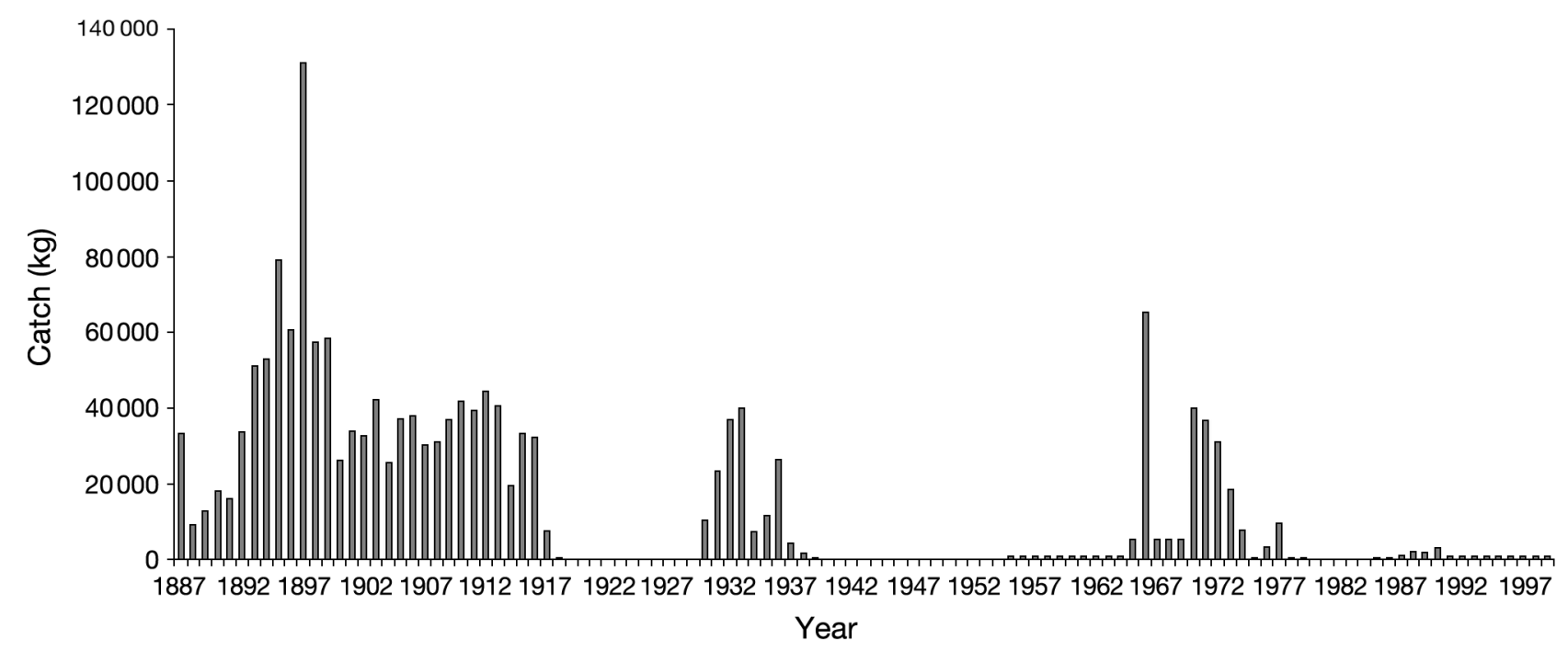

Fig. 1. Petromyzon marinus and Lampetra fluviatilis. Total landings in the southern coastal parts of ICES Subdivisions 24-26 of the Baltic Sea from 1887 to 1999. Data largely for the river lamprey Lampetra fluviatilis but may include some sea lamprey Petromyzon marinus as species were not distinguished in the past

Roughly $65.3 \%$ of the mean annual yield of lampreys was found in the lower Vistula River, Vistula Lagoon and the Bay of Gdańsk, followed by the Szczecin Lagoon and adjacent waters (18.4\%) and the Curonian Lagoon and Nemunas Delta (16.3\%; Table 2). The relative contribution of the lower Vistula River, Vistula Lagoon and the Bay of Gdańsk increased remarkably from 1887 to 1939, whereas the relative importance of the Szczecin Lagoon and adjacent waters for the lamprey fishery decreased during the same period of time. Lamprey catches originated nearly exclusively from the lower Vistula River, Vistula Lagoon and the Bay of Gdańsk from 1920 to
1939. A remarkable proportion of lamprey catches after 1950 come from the Curonian Lagoon and Nemunas Delta (Table 2).

Seasonal values of commercial catches of river lamprey were available for the Szczecin Lagoon and adjacent waters, the Vistula Lagoon and the Curonian Lagoon. Seasonal river lamprey catch showed maximum values from August to December and reached a peak in October and November for each of the 3 areas compared (Fig. 2). A small spring component (March) of seasonal catches that was hardly noticeable was indicated for the Vistula Lagoon.

Table 2. Lampetra fluviatilis. Mean annual total catch $(\mathrm{kg})$ of river lamprey in the southern Baltic Sea (territorial waters and EEZs of Germany, Poland and Lithuania in ICES Subdivisions 24 to 26; no catches were reported for Subdivision 25) and in selected parts of that area at different time periods from 1887 to 1999. Mean: mean annual total catch from 1887 to 1999

\begin{tabular}{|c|c|c|c|c|}
\hline & \multirow{2}{*}{$\begin{array}{l}\text { Total catch } \\
\text { southern Baltic }\end{array}$} & \multirow{2}{*}{$\begin{array}{l}\text { Mean an } \\
\text { Subdivision } 24 \\
\text { Szczecin Lagoon } \\
\text { and adjacent waters }\end{array}$} & \multicolumn{2}{|c|}{ Subdivision 26} \\
\hline & & & $\begin{array}{l}\text { Lower Vistula River, Vistula } \\
\text { Lagoon and Bay of Gdańsk }\end{array}$ & $\begin{array}{l}\text { Curonian Lagoon } \\
\text { and Nemunas Delta }\end{array}$ \\
\hline $1887-1889$ & 18564.33 & 2526.67 & 6215.67 & 9822.00 \\
\hline 1890-1899 & 44430.40 & 16129.00 & 20845.20 & 7456.20 \\
\hline 1900-1909 & 38249.90 & 7957.50 & 27504.00 & 2788.40 \\
\hline 1910-1919 & 32793.60 & 2343.00 & 27434.40 & 3016.20 \\
\hline 1920-1929 & 52.60 & 0.00 & 52.60 & 0.00 \\
\hline 1930-1939 & 1090.00 & 0.00 & 970.00 & 120.00 \\
\hline 1950-1959 & 400.00 & 0.00 & 0.00 & 400.00 \\
\hline 1960-1969 & 9000.00 & 0.00 & 6000.00 & 3000.00 \\
\hline 1970-1979 & 14813.60 & 0.00 & 11203.60 & 3610.00 \\
\hline 1980-1989 & 595.60 & 0.00 & 555.60 & 40.00 \\
\hline 1990-1999 & 1083.60 & 45.00 & 198.60 & 840.00 \\
\hline Mean: 1887-1999 & 14376.56 & 2643.93 & 9381.43 & 2351.20 \\
\hline Percentage & 100.00 & 18.39 & 65.26 & 16.35 \\
\hline
\end{tabular}




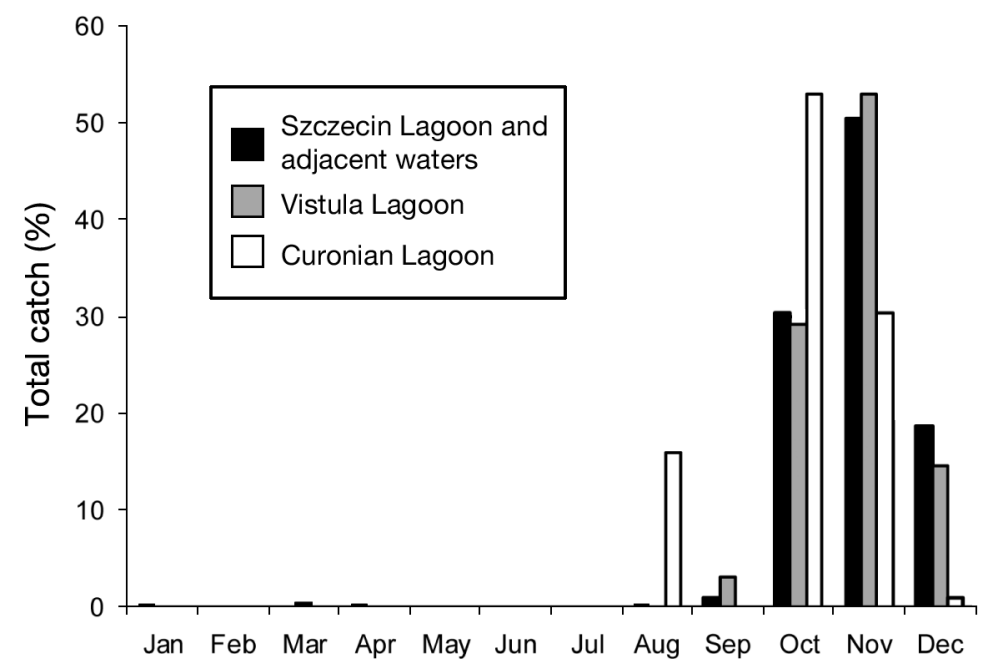

Fig. 2. Lampetra fluviatilis. Seasonal variation in total catches of river lamprey in the Szczecin, Vistula and Curonian Lagoons from 1887 to 1920

sion 26. Subdivision 22 provided 17 records (5.5\%). Only 4 observations $(1.3 \%)$ of the river lamprey were made in Subdivision 25 (Table 1).

The oldest record of the river lamprey dates back to the year 1649, when this species was recorded in the Szczecin Lagoon near the city of Ueckermuende (Table S2). Some 174 records of river lampreys were summarised for the time period 1649 to 1939 (Table S2, Fig. 5). From 1940 to 1989, 66 records of the river lamprey were obtained (Table S2, Fig. 5). A total of 70 records originated from German and adjacent Polish Baltic waters in Subdivisions 22 and 24 from 1990 to 2005 (Table 4, Fig. 6). During this time interval, river lampreys were recorded from the Salzhaff, the Warnow River, the Recknitz River, from around Ruegen Island, the Pommeranian Bay, from the Szczecin Lagoon and adjacent waters, and from

\section{Sea lamprey: past and present distribution in Subdivisions 22 and 24 to 26}

Generally, most sea lampreys were recorded from the most western and middle Subdivisions 22 (16 records, 29.6\%) and 24 (36 records, 66.7\%; Table 1, Figs. $3 \& 4)$. Only 2 records ( $3.7 \%$ ) of sea lamprey were available in the eastern Subdivision 26, and no record was reported for Subdivision 25. Most records were distributed within territorial coastal waters and estuaries (Figs. $3 \& 4$ ). Offshore records of this species were rare.

The oldest sea lamprey record dates back to the year 1855 from the Greifswald Bodden (Pommeranian Coast, south of Ruegen Island) in Subdivision 24 (Table S1). The analysis of relevant records resulted in 11 observations of sea lampreys in the considered area for the time period 1855 to 1939 (Table S1, Fig. 3). From 1940 to 1989, sea lamprey was recorded 29 times (Table S1, Fig. 3). Fourteen records of sea lamprey were obtained in German and adjacent Polish waters in Subdivisions 22 and 24 in the 1990 to 2005 period (Table 3, Fig. 4).

\section{River lamprey: past and present distribution in Subdivisions 22 and 24 to 26}

In contrast to the sea lamprey, numerous records of the river lamprey were obtained both from western and eastern parts of the considered area (Table 1, Figs. $5 \& 6$ ). Approximately half of the observations of river lamprey came from Subdivision 24 (151 records, $48.7 \%$ ), whereas 138 (44.5\%) originated from Subdivi-
9 spawning sites in German tributaries of the Baltic Sea (Fig. 6).

During the time period 1649 to 1989 , the species was mainly distributed within the following 3 areas of Subdivisions 22 and 24 to 26 (Table S2, Fig. 5):

- Szczecin Lagoon and adjacent waters (Subdivision 24)

- Lower Vistula River, Vistula Lagoon and Bay of Gdańsk (Subdivision 26)

- Curonian Lagoon (Subdivision 26)

Remarkable numbers of records of river lampreys were also obtained from the Kiel Bight, the Mecklenburg Bight, the mouth of the River Warnow and from the waters around Ruegen Island during the period 1649 to 1939 (Table S2, Fig. 5). However, from 1940 to 1989, the river lamprey was not recorded from the Kiel Bight, and the number of records in the southwest Mecklenburg Bight was much lower than in the previous time period (Table S2, Fig. 5).

Within the German and adjacent Polish waters of Subdivisions 22 and 24, most of the records (81.4\%) and recorded individuals $(98.3 \%)$ originated from the Szczecin Lagoon and its adjacent waters during the period 1990 to 2005 (Table 4, Fig. 6), demonstrating the current importance of these water bodies for the spawning migrations of this species.

\section{DISCUSSION}

The results of the present study clearly indicate that, compared to the river lamprey, the sea lamprey is a rare species in the southern Baltic Sea. Subdivisions 22 and 24 are the main past and present distribution areas 
of this species. Furthermore, our results show no clear increasing or decreasing trend of sea lamprey densities in the considered area of the southern Baltic Sea during the last centuries.

Most sea lamprey records in the considered area originate from territorial coastal waters. However, Thiel et al. (2007) reported a few sea lampreys in the Baltic Sea from offshore areas, especially in ICES Subdivisions 21 and 25. Kottelat \& Freyhof (2007) also indicated the importance of offshore habitats for this species. Lelek (1973) stated that sea lampreys can be found in the open sea up to several hundred kilometres away from the coast. This is corroborated by a record of sea lamprey in a Nephrops trawl off the Porcupine Bank, $230 \mathrm{~km}$ off the west of Ireland (Igoe et al. 2004). Almost all sea lampreys that were <390 mm long were captured in the northwest Atlantic in bottom trawls on the continental shelf or in coastal trap nets, whereas most animals that were $>560 \mathrm{~mm}$ long were captured in mid-water trawls along the shelf edge or over the continental slope (Halliday \& Mott 1991). The vertical depth range inhabited by sea lampreys is among the greatest ranges exhibited by marine animals (Haedrich 1977, Beamish 1980), with reports of findings down to 985 and 4099 m (Kelly \& King 2001).

Although the sea lamprey was found to have low densities in the present study and is also regarded as rare in the Baltic Sea region by other authors (e.g. Winkler et al. 2000), this species has occasionally been reported from Denmark, Sweden, Finland, Russia, Latvia, Lithuania, Estonia, Poland and Germany (Kull 1999, Winkler et al. 2000, Froese \& Pauly 2008).

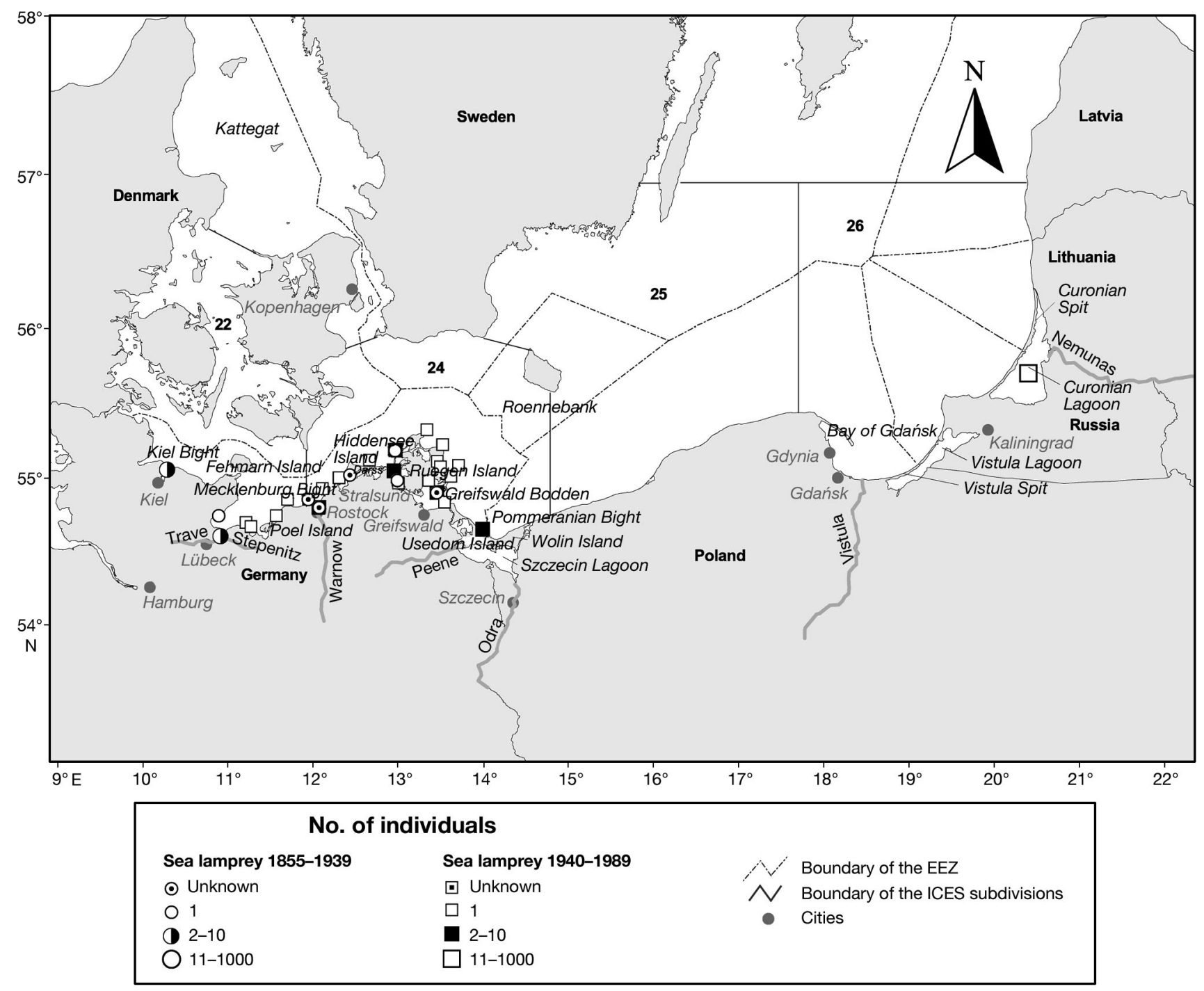

Fig. 3. Petromyzon marinus. Distribution of historical sea lamprey records in territorial waters and in the Exclusive Economic Zones (EEZs) of Germany, Poland, Lithuania and the Russian enclave of Kaliningrad within ICES Subdivisions 22 and 24-26 of the southern Baltic Sea for 1855 to 1939 and 1940 to 1989 
However, the Baltic Sea is located at latitudes that are higher than the main distribution area of sea lamprey between latitudes $35^{\circ}$ and $45^{\circ}$ (Kelly \& King 2001). Although Saat (2003) reported 20 confirmed catches of sea lamprey from Estonian waters (mainly from the Gulf of Riga) during the 20th century, there is no reliable data on sea lamprey reproduction in Estonian rivers. Moreover, from which spawning population the sea lampreys recorded in German waters of the Baltic Sea in the present study originate is also still an open question. Historically, the sea lamprey might have spawned in the Trave River system (Duncker 1960), although there are no observations from recent years showing that this spawning site is still being used by sea lampreys (Spratte 2004). Indeed, there is no evidence of recent sea lamprey reproduction in the entire Baltic Sea (Spratte \& Hartmann 1998, Winkler et al. 2002). However, Ljunggren (2006) noted that sea lampreys have been reported in 18 rivers in Sweden since 1990, but that spawning sea lampreys were only observed in 8 rivers, mainly in those flowing into the Kattegat and Öresund. Prob-

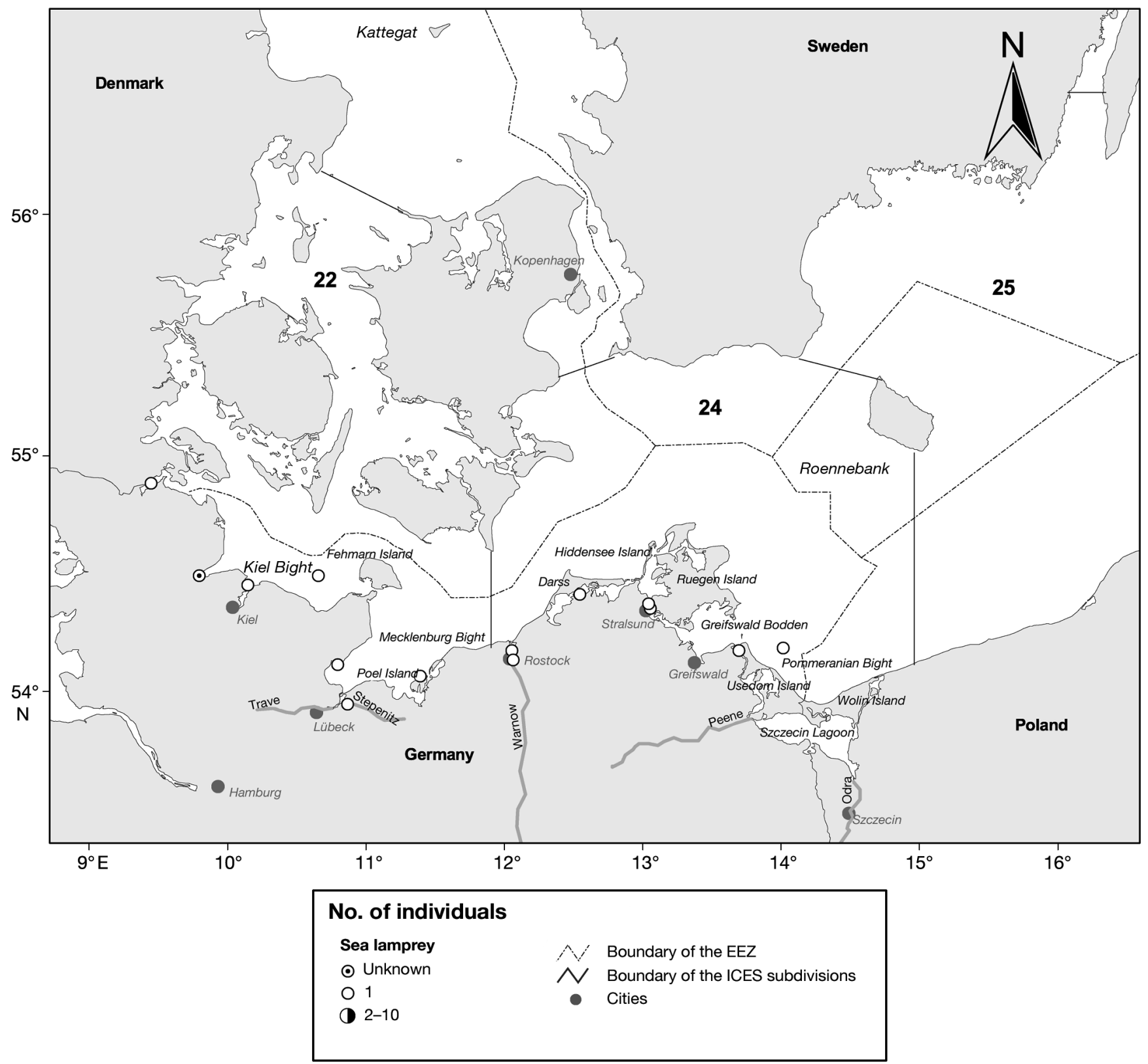

Fig. 4. Petromyzon marinus. Distribution of recent sea lamprey records in territorial waters and in the EEZ of Germany and in adjacent Polish waters within ICES Subdivisions 22 and 24 of the Baltic Sea from 1990 to 2005 
Table 3. Petromyzon marinus. Recent sea lamprey records in territorial waters and in the EEZ of Germany and in adjacent Polish waters within ICES Subdivisions 22 and 24 of the Baltic Sea from 1990 to 2005. ZMUK: Zoological Museum of the ChristianAlbrechts-University Kiel, Germany; ZSRO: Zoological collection of the Department of Biology of the University of Rostock, Germany; vTI-OSF: Institute of Baltic Sea Fisheries. -: no data available

\begin{tabular}{|ccllccc|}
\hline Year & Subdivision & Country & Locality & No. of ind. & $\begin{array}{c}\text { Total } \\
\text { length }(\mathrm{cm})\end{array}$ & Data source \\
\hline 1991 & 24 & Germany & Strelasund near Stralsund & 1 & 49 & Schröder (1995) \\
1992 & 24 & Germany & Strelasund & 1 & 85 & Schröder (1995) \\
1998 & 24 & Germany & Lower Warnow River & 1 & - & ZSRO \\
1999 & 22 & Germany & Kiel Bight & 1 & - & ZMUK \\
2000 & 22 & Germany & Neustadt Bight & 1 & - & Spratte (2004) \\
2001 & 24 & Germany & Coastal waters of Usedom Island & 1 & 43 & Thiel et al. (2005) \\
2001 & 24 & Germany & Darss Zingst Estuary near Born & 1 & 66 & Anders (2002) \\
2002 & 22 & Germany & Flensburg Bight & Unknown & - & Spratte (2004) \\
2002 & 22 & Germany & Schlei & 1 & 64.5 & Spratte (2004) \\
2003 & 22 & Germany & Howacht Bight & 1 & - & vTI-OSF \\
2003 & 24 & Germany & Warnow River & 1 & - & Thiel et al. (2005) \\
2004 & 22 & Germany & Dassower See & 1 & 60 & Thiel et al. (2005) \\
2005 & 22 & Germany & Poel Island near Gollwitz & Thiel et al. (2005) \\
2005 & 24 & Germany & Peenestrom & & Thiel et al. (2005) \\
\end{tabular}

ably, the recently recorded sea lampreys in the German Baltic waters originate from these Swedish spawning populations.

Our results demonstrate that in contrast to the rare sea lamprey, the river lamprey is generally a common and widely distributed member of the ichthyofauna of the Baltic Sea, its estuaries and tributaries. In the Baltic Sea region, populations of the river lamprey occur in Denmark, Sweden, Finland, Russia, Latvia, Lithuania, Estonia, Poland and Germany (Bartel et al. 1993, Anonymous 1998, Winkler et al. 2000). Although the species is mainly anadromous in the Baltic Sea area, there are a few landlocked, nonmigratory populations that have been isolated from the sea in Finland (Tuunainen et al. 1980, Valtonen 1980) and possibly also in Russia (e.g. Abakumov 1956, Reshetnikov 2003). River lampreys live predominantly in coastal areas, especially near estuaries (Hardisty 1986). However, Thiel et al. (2007) also summarised a few records of river lampreys outside coastal waters of the Baltic Sea.

The sea lamprey has never been a commercial species in the Baltic Sea. However, it is commercially important in France, Spain and Portugal (Maitland \& Campbell 1992). Among the rivers along the European coast that are still colonised by the sea lamprey, the Garonne Basin has the largest population of sea lamprey. This basin supports the largest fisheries of sea lamprey in Europe (Beaulaton et al. 2008).

Unlike the findings for the sea lamprey, the present study has shown that the German, Polish and Lithuanian waters of the Baltic Sea, especially within Subdivisions 24 and 26, were the main distribution and also fishery areas of river lampreys in the past. Approxi- mately $100 \mathrm{yr}$ ago, the river lamprey was an important commercial species for coastal fisheries in southern Baltic waters. In Germany, no lamprey fishery occurs any more, but our results show that the river lamprey was used commercially in Poland and Lithuania at lower levels at least until 1999. However, it should be noted that since World War II there appears to have been less comprehensive registration of lamprey catch than in earlier periods. In the north of Sweden, river lamprey was once also a very important commercial species, but the amounts of spawning river lampreys and catches have declined since the middle of the 1960s (Sjölander 1997).

In rivers of Finland, Russia, Latvia and Estonia, the commercial fishery of lamprey is still active (Anonymous 1998, Saat et al. 2000, Lehtonen 2006). However, annual catches have decreased in recent decades, although the fishery has become more effective, e.g. in Finland (Ojutkangas et al. 1995). In Finland, total catches in 1978 and 1988 were estimated to be 2.32.5 million ind. (Tuunainen et al. 1980) and 1.8-1.9 million ind. (Mäkelä \& Kokko 1990), respectively. The main reasons for the decrease are the building of hydroelectric power plants, and the short-term regulation and dredging of rivers. As a result, suitable spawning and nursery habitats for lampreys have decreased; this resulted in a reduction in the number of mature lampreys migrating upstream (Kainua \& Valtonen 1980, Eklund et al. 1984).

The seasonal pattern of catch estimated in the present study indicates that lampreys in the whole southern Baltic Sea region were mainly caught during their spawning migrations. This pattern was also observed by Sterner (1918) and Imam et al. (1958) who investi- 
gated lamprey catches in rivers flowing into the North Sea. Kelly \& King (2001) did not mention fisheries but instead concluded that populations of anadromous lampreys have declined in European inland waters mainly due to pollution, the construction of dams (associated with hydroelectric power stations), weirs and other manmade barriers in rivers, channelisation and land-management practices that have led to increased siltation on spawning gravels (Hunn \& Youngs 1980, Kainua \& Valtonen 1980, Valtonen 1980, Eklund et al. 1984, Witkowski 1992, Ojutkangas et al. 1995, Meyer \& Brunken 1997). In German inland waters, Imam et al. (1958), Wilkens \& Köhler (1977), Möller (1984), Thiel \& Salewski (2003), Krappe (2004) and Spratte (2004) observed a considerable decrease in anadromous lamprey populations during the mid 1950s. Lelek (1987) assumed that pollution of estuaries and the building of weirs and dams prevented lampreys from reaching their original spawning grounds.

Spratte (2004) concluded that an increased number of records of river lampreys in inland waters of northwest Germany (Schleswig-Holstein) in recent years could be attributed to improved water quality in the rivers. In almost all rivers and streams in the catchment of the River Rhine, water quality has improved considerably, and the problems of low oxygen concentrations have become unimportant since the early 1980s (Freyhof 2002). Therefore, populations of river

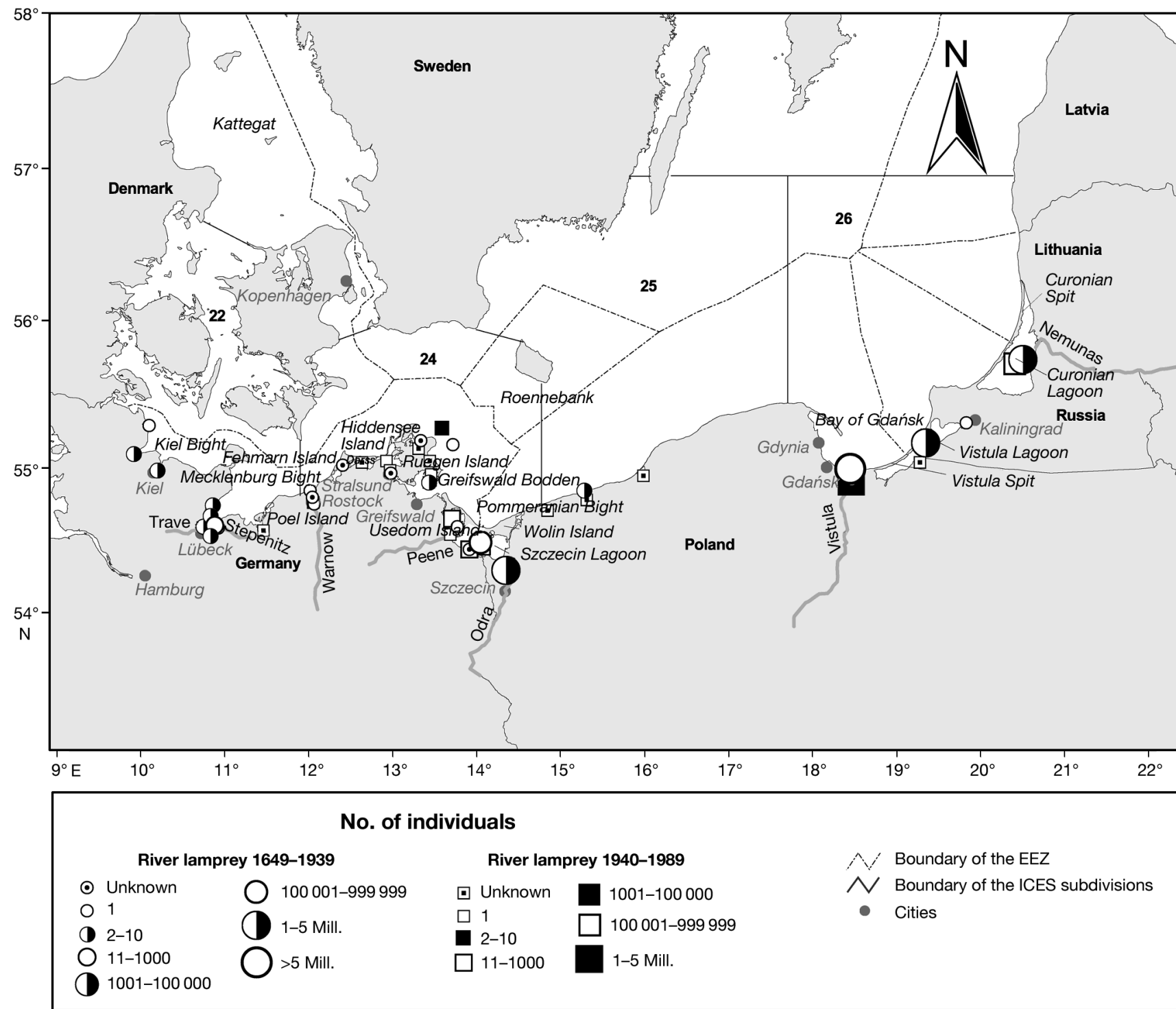

Fig. 5. Lampetra fluviatilis. Distribution of historical records of river lamprey in territorial waters and in the EEZs of Germany, Poland, Lithuania and the Russian enclave of Kaliningrad within ICES Subdivisions 22 and 24-26 of the southern Baltic Sea for 1649 to 1939 and 1940 to 1989 
and sea lamprey have recovered there (Freyhof \& Weibel 1999, Korte 1999). However, the situation of river lamprey populations in northeast Germany (Mecklenburg-Vorpommern) is still critical (Winkler et al. 2002). Only 9 spawning sites used by river lampreys are known in German tributaries of the Baltic Sea (Winkler et al. 1999, Waterstraat \& Krappe 2000). These spawning sites were found in the Peene, Warnow and Stepenitz river systems (Fig. 6). The Peene River system must be regarded as the most important of these in the German Baltic Sea region. Here, 5 spawning sites were thought to exist, in the Scheidegraben, Augraben, Galgenbach, Klenzer Muehlbach and Libnower Muehlbach tributaries. The Warnow River system provides 3 spawning places in the Beke and Koesterbeck tributaries and in the Muehlendamm canal near the city of Rostock. Only 1 spawning site was found in Radegast, a tributary of the Stepenitz River. Winkler et al. (1999) emphasised that the regular annual spawning of river lamprey no

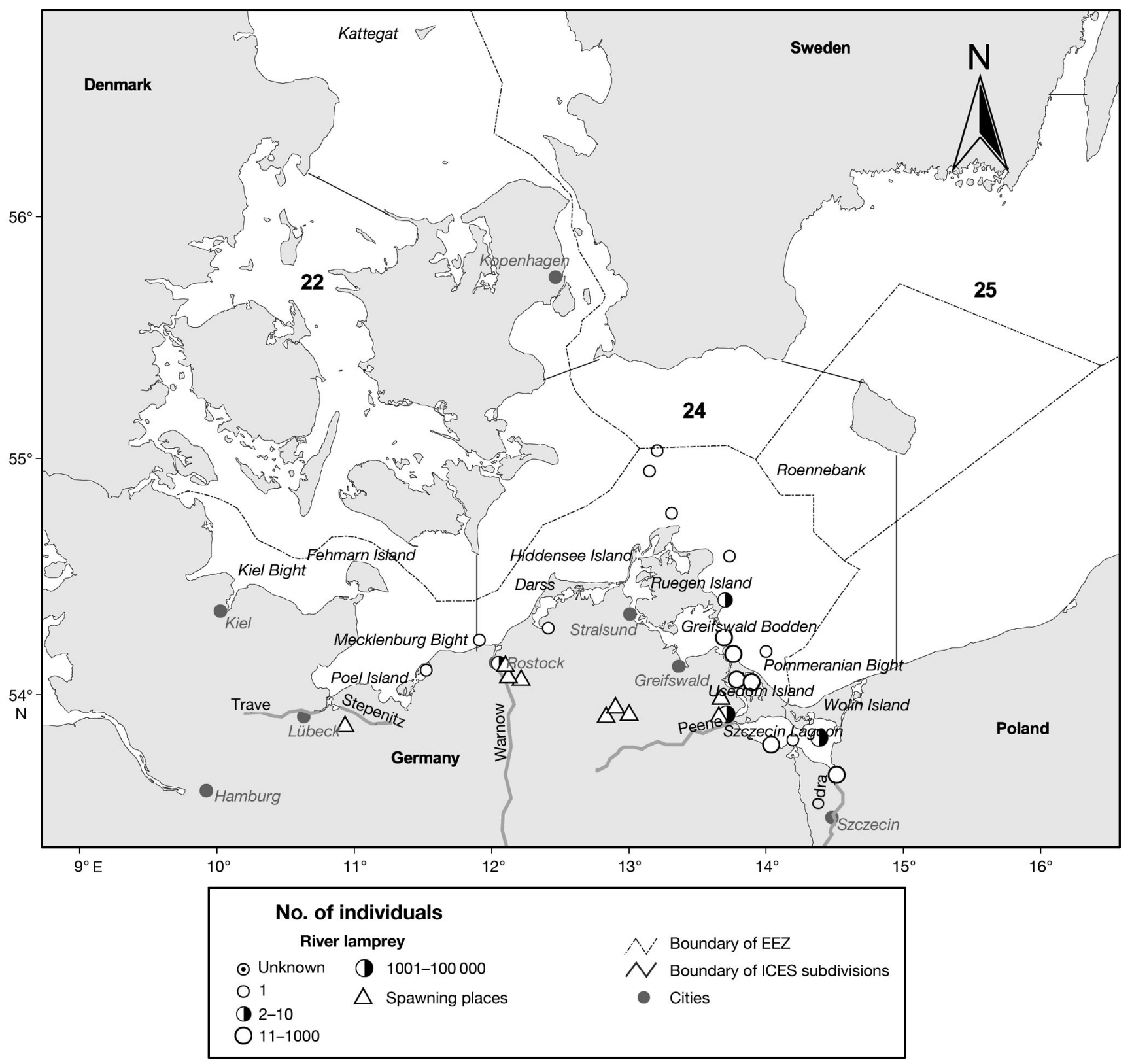

Fig. 6. Lampetra fluviatilis. Distribution of recent river lamprey records in territorial waters and in the EEZ of Germany and in adjacent Polish waters within ICES Subdivisions 22 and 24 of the Baltic Sea from 1990 to 2005, and location of detected spawning sites in German tributaries of the southern Baltic Sea 
Table 4. Lampetra fluviatilis. Recent records of river lamprey in territorial waters and in the EEZ of Germany and in adjacent Polish waters within ICES Subdivisions 22 and 24 from 1990 to 2005. GOMS: German Oceanographic Museum, Stralsund, Germany; NHMB: Museum of Natural History of the Humboldt University, Berlin, Germany; vTI-OSF: Institute of Baltic Sea Fisheries. -: No data available

\begin{tabular}{|c|c|c|c|c|c|c|c|}
\hline No. & Year & $\begin{array}{c}\text { Sub } \\
\text { division }\end{array}$ & Country & Locality & $\begin{array}{l}\text { No. of } \\
\text { ind. }\end{array}$ & $\begin{array}{c}\text { Total } \\
\text { length }(\mathrm{cm})\end{array}$ & Data source \\
\hline 1 & 1990 & 24 & Poland & Odra River & 1 & - & NHMB \\
\hline 2 & 1990 & 24 & Poland & Szczecin Lagoon & 4500 & - & Raczyński \& Filipiak (1999) \\
\hline 3 & 1994 & 24 & Germany & Ruden Island & 50 & $\max .35$ & Schröder (1995) \\
\hline 4 & 1994 & 24 & Germany & Usedom Island & 50 & max. 35 & Schröder (1995) \\
\hline 5 & 1995 & 24 & Germany & North of Ruegen Island & 1 & 43.5 & vTI-OSF \\
\hline 6 & 1996 & 24 & Germany & Northeast of Ruegen Island & 1 & 35.5 & vTI-OSF \\
\hline 7 & 1997 & 22 & Germany & Salzhaff & 1 & - & GOMS \\
\hline 8 & 1997 & 24 & Germany & Northwest of Ruegen Island & 1 & 35.5 & vTI-OSF \\
\hline 9 & 1997 & 24 & Poland & Lake Dabie & 35 & - & Raczyński \& Filipiak (1999) \\
\hline 10 & 1998 & 24 & Poland & Lake Dabie & 53 & - & Raczyński \& Filipiak (1999) \\
\hline 11 & 1999 & 24 & Germany & Libnower Muehlbach & 2000 & - & Waterstraat \& Krappe (2000) \\
\hline 12 & 1999 & 24 & Germany & North of Ruegen Island & 1 & - & Kloppmann et al. (2003) \\
\hline 13 & 1999 & 24 & Germany & Northwest of Ruegen Island & 1 & - & Kloppmann et al. (2003) \\
\hline 14 & 2003 & 24 & Germany & Coastal waters of Usedom Island & 1 & $\sim 35$ & Thiel et al. (2007) \\
\hline 15 & 2003 & 24 & Germany & Szczecin Lagoon near Altwarp & 1 & Adult & Thiel et al. (2007) \\
\hline 16 & 2003 & 24 & Germany & Warnow River & 6 & Adult & Thiel et al. (2007) \\
\hline 17 & 2004 & 24 & Germany & Krumminer Wiek & 1 & 36 & Thiel et al. (2007) \\
\hline 18 & 2004 & 24 & Germany & Krumminer Wiek & 3 & $30-35$ & Thiel et al. (2007) \\
\hline 19 & 2004 & 24 & Germany & Krumminer Wiek & 7 & $30-40$ & Thiel et al. (2007) \\
\hline 20 & 2004 & 24 & Germany & Krumminer Wiek & 1 & 38 & Thiel et al. (2007) \\
\hline 21 & 2004 & 24 & Germany & Krumminer Wiek & 1 & 35 & Thiel et al. (2007) \\
\hline 22 & 2004 & 24 & Germany & Krumminer Wiek & 1 & 40 & Thiel et al. (2007) \\
\hline 23 & 2004 & 24 & Germany & Krumminer Wiek & 1 & 34 & Thiel et al. (2007) \\
\hline 24 & 2004 & 24 & Germany & Krumminer Wiek & 1 & 36 & Thiel et al. (2007) \\
\hline 25 & 2004 & 24 & Germany & Krumminer Wiek & 1 & 32 & Thiel et al. (2007) \\
\hline 26 & 2004 & 24 & Germany & Krumminer Wiek & 1 & 38 & Thiel et al. (2007) \\
\hline 27 & 2004 & 24 & Germany & Krumminer Wiek & 3 & $30-34$ & Thiel et al. (2007) \\
\hline 28 & 2004 & 24 & Germany & Krumminer Wiek & 2 & $33 ; 40$ & Thiel et al. (2007) \\
\hline 29 & 2004 & 24 & Germany & Krumminer Wiek & 1 & 40 & Thiel et al. (2007) \\
\hline 30 & 2004 & 24 & Germany & Krumminer Wiek & 2 & $38 ; 40$ & Thiel et al. (2007) \\
\hline 31 & 2004 & 24 & Germany & Krumminer Wiek & 1 & 33 & Thiel et al. (2007) \\
\hline 32 & 2004 & 24 & Germany & Krumminer Wiek & 1 & 34 & Thiel et al. (2007) \\
\hline 33 & 2004 & 24 & Germany & Krumminer Wiek & 1 & 32 & Thiel et al. (2007) \\
\hline 34 & 2004 & 24 & Germany & Krumminer Wiek & 1 & 37 & Thiel et al. (2007) \\
\hline 35 & 2004 & 24 & Germany & Krumminer Wiek & 3 & $31-35$ & Thiel et al. (2007) \\
\hline 36 & 2004 & 24 & Germany & Krumminer Wiek & 2 & 40 & Thiel et al. (2007) \\
\hline 37 & 2004 & 24 & Germany & Krumminer Wiek & 1 & 31 & Thiel et al. (2007) \\
\hline 38 & 2004 & 24 & Germany & Krumminer Wiek & 1 & 37 & Thiel et al. (2007) \\
\hline 39 & 2004 & 24 & Germany & Krumminer Wiek & 3 & $30-35$ & Thiel et al. (2007) \\
\hline 40 & 2004 & 24 & Germany & Krumminer Wiek & 2 & $37 ; 40$ & Thiel et al. (2007) \\
\hline 41 & 2004 & 24 & Germany & Recknitz River & 1 & - & Thiel et al. (2007) \\
\hline 42 & 2004 & 24 & Germany & Szczecin Lagoon nr. Ueckermuende & 1 & 39 & Thiel et al. (2007) \\
\hline 43 & 2004 & 24 & Germany & Szczecin Lagoon nr. Ueckermuende & 1 & 36 & Thiel et al. (2007) \\
\hline 44 & 2004 & 24 & Germany & Szczecin Lagoon nr. Ueckermuende & 1 & 38 & Thiel et al. (2007) \\
\hline 45 & 2004 & 24 & Germany & Szczecin Lagoon nr. Ueckermuende & 1 & 36 & Thiel et al. (2007) \\
\hline 46 & 2004 & 24 & Germany & Szczecin Lagoon nr. Ueckermuende & 1 & 36.5 & Thiel et al. (2007) \\
\hline 47 & 2004 & 24 & Germany & Szczecin Lagoon nr. Ueckermuende & 1 & 37.5 & Thiel et al. (2007) \\
\hline 48 & 2004 & 24 & Germany & Szczecin Lagoon nr. Ueckermuende & 1 & 38 & Thiel et al. (2007) \\
\hline 49 & 2004 & 24 & Germany & Szczecin Lagoon nr. Ueckermuende & 1 & 32 & Thiel et al. (2007) \\
\hline 50 & 2004 & 24 & Germany & Szczecin Lagoon nr. Ueckermuende & 1 & 35 & Thiel et al. (2007) \\
\hline 51 & 2004 & 24 & Germany & Szczecin Lagoon nr. Ueckermuende & 1 & 35 & Thiel et al. (2007) \\
\hline 52 & 2004 & 24 & Germany & Szczecin Lagoon nr. Ueckermuende & 23 & $32-42$ & Thiel et al. (2007) \\
\hline 53 & 2004 & 24 & Germany & Szczecin Lagoon nr. Ueckermuende & 1 & 42 & Thiel et al. (2007) \\
\hline 54 & 2004 & 24 & Germany & Szczecin Lagoon nr. Ueckermuende & 1 & 36.5 & Thiel et al. (2007) \\
\hline 55 & 2004 & 24 & Germany & Szczecin Lagoon nr. Ueckermuende & 3 & - & Thiel et al. (2007) \\
\hline 56 & 2004 & 24 & Germany & Szczecin Lagoon nr. Ueckermuende & 1 & 35 & Thiel et al. (2007) \\
\hline 57 & 2004 & 24 & Germany & Szczecin Lagoon nr. Ueckermuende & 1 & 34 & Thiel et al. (2007) \\
\hline 58 & 2004 & 24 & Germany & Szczecin Lagoon nr. Ueckermuende & 1 & 40 & Thiel et al. (2007) \\
\hline 59 & 2004 & 24 & Germany & Szczecin Lagoon nr. Ueckermuende & 1 & 38.5 & Thiel et al. (2007) \\
\hline
\end{tabular}


Table 4 (continued)

\begin{tabular}{|cccccccc|}
\hline No. Year & $\begin{array}{c}\text { Sub } \\
\text { division }\end{array}$ & Country & \multicolumn{1}{c}{ Locality } & $\begin{array}{c}\text { No. of } \\
\text { ind. }\end{array}$ & $\begin{array}{c}\text { Total } \\
\text { length (cm) }\end{array}$ & Data source \\
\hline 60 & 2004 & 24 & Germany & Szczecin Lagoon nr. Ueckermuende & 1 & 40.5 & Thiel et al. (2007) \\
61 & 2004 & 24 & Germany & Szczecin Lagoon nr. Ueckermuende & 1 & 37 & Thiel et al. (2007) \\
62 & 2004 & 24 & Germany & Szczecin Lagoon nr. Ueckermuende & 1 & 41 & Thiel et al. (2007) \\
63 & 2004 & 24 & Germany & Szczecin Lagoon nr. Ueckermuende & 1 & 35 & Thiel et al. (2007) \\
64 & 2004 & 24 & Germany & Szczecin Lagoon nr. Ueckermuende & 1 & 38.5 & Thiel et al. (2007) \\
65 & 2004 & 24 & Germany & Szczecin Lagoon nr. Ueckermuende & 1 & 38 & Thiel et al. (2007) \\
66 & 2004 & 24 & Germany & Szczecin Lagoon nr. Ueckermuende & 1 & 40 & Thiel et al. (2007) \\
67 & 2005 & 24 & Germany & Warnemünde & 1 & 37 & Thiel et al. (2007) \\
68 & 2005 & 24 & Germany & Ruegen Island nr. Göhren & 4 & - & Thiel et al. (2007) \\
69 & 2005 & 24 & Germany & Krumminer Wiek & 1 & - & Thiel et al. (2007) \\
70 & 2005 & 24 & Germany & Achterwasser & 17 & - & Thiel et al. (2007) \\
\hline
\end{tabular}

longer occurs in all spawning sites. Furthermore, the spawning populations of river lamprey are very small, comprising only 20 to 100 ind. (Winkler et al. 2002).

\section{CONCLUSIONS}

The results of the present study confirm the critical situation of the populations of river lamprey, especially in the German Baltic Sea area. Here, a rebuilding programme for the still existing but threatened populations of river lampreys could improve the situation of the species. Such a rebuilding programme should contain measures to restore lost spawning sites and the connectivities of the river systems that support them to ensure that lampreys reach their spawning sites during their spawning migrations. The habitat connectivity for the river lamprey can be increased by the removal of barriers and weirs or the provision of fish passages in rivers where their spawning and nursery habitats are situated. Leipe \& Königstedt (1988), Waterstraat \& Krappe (2000), Petersen et al. (2004) and Spratte (2004) describe measures for river lamprey rebuilding programmes in German rivers in more detail. In 2004, Germany nominated a number of SACs in German Baltic waters to the EU Commission. These SACs also cover parts of the estuarine Szczecin Lagoon and adjacent waters, where the main migration route of river lampreys to their most numerous spawning sites was detected during the present study. Such protected areas can be additional measures for the conservation of the species in these waters. The results of the present study, do not enable us to recommend any special rebuilding programmes for the sea lamprey for the German waters of the Baltic Sea region. Obviously, the sea lamprey has always been a rare and not a stock building species in German Baltic waters. It is, however, possible that sea lamprey would also benefit from river lamprey rebuilding programmes.
Acknowledgements. We thank B. Bruns, J. Heischkel, V. Huckstorf, D. Lill, N. Löser and R. Weigel for their helpful contributions to and comments on this study. The study was assigned by the German Federal Agency for Nature Conservation and sponsored by the Federal Ministry for the Environment, Nature Conservation and Nuclear Safety under grant no. 80385220 .

\section{LITERATURE CITED}

Abakumov VA (1956) On the life history of the river lamprey from the Baltic Sea. Vopr Ikhtiol 6:122-128

Anders E (2002) Meerneunauge in der Darss-Zingster Boddenkette gefangen. Fischerei \& Fischmarkt in Mecklenburg-Vorpommern 2/2002:32

Anonymous (1998) Sector report on fisheries. Contribution to Baltic 21. Baltic 21 Series No 4/98, p 69

Anonymous (2001) Krasnaya Kniga Rossiyskoy Federatsii. Zhivotnye (Red book of the Russian Federation. Animals). Ast and Astrel-Balashikha, Aginskoe, p 862

Bartel R, Bradauskas B, Ikonen E, Mitans A and others (1993) Comparison of length and weight of river lamprey from Finland, Latvia, Lithuania and Poland. ICES CM 1993/M: $17, \mathrm{p} 8$

Beamish FWH (1980) Biology of the North American anadromous sea lamprey, Petromyzon marinus. Can J Fish Aquat Sci 37:1924-1943

Beaulaton L, Taverny C, Castelnaud G (2008) Fishing, abundance and life history traits of the anadromous sea lamprey (Petromyzon marinus) in Europe. Fish Res 92:90-101

Duncker G (1960) Die Fische der Nordmark. Abhandlungen und Verhandlungen des Naturwissenschaftlichen Vereins in Hamburg. N. F. Vol III, Supplement, Kommissionsverlag Cram, De Gruyter, Hamburg, p 432

Economidis PS, Kallianiotis A, Psaltopoulou H (1999) Two records of sea lamprey from the north Aegean Sea. J Fish Biol 55:1114-1118

Eklund J, Niemi A, Ojutkangas E (1984) The river lamprey in 2 regulated Finnish rivers. In: Lillehammer A, Saltweit $S$ (eds) Regulated rivers. Universitetsforlaget, Oslo, Vol 2, p 417-426

Environmental Systems Research Institute (ESRI) (2002) ArcView GIS, version 3.3., Redlands, CA

Erguven H (1989) An investigation on the determination of the parasitic form of Petromyzonidae living in the streams running to Sepanca Lake. Su Urunleri Dergisi/Journal of Aquatic Products 3:29-36 (in Turkish) 
Freyhof J (2002) Chapter 1. Freshwater fish diversity in Germany, threats and species extinction. In: Collares-Pereira MJ, Cowx IG, Coelho MM (eds.) Conservation of freshwater fishes: options for the future. Fishing News Books, Blackwell Science, Oxford, London, p 3-22

Freyhof J, Weibel U (1999) Vorschlag einer Neufassung der Roten Liste der bestandsgefährdeten Neunaugen und Fische (Petromyzontiformes; Teleostei) in Rheinland-Pfalz sowie ein Verzeichnis aller vorkommenden Arten. Fauna Flora Rheinland-Pfalz 9:195-206

Fricke R, Rechlin O, Winkler H, Bast HDO, Hahlbeck E (1996) Rote Liste und Artenliste der Rundmäuler und Meeresfische des deutschen Meeres- und Küstenbereichs der Ostsee. Schrreihe Landschaftspfl Natursch 48:83-90

Froese R, Pauly D (2008). FishBase. www.fishbase.org, accessed 5 June, 2008

Głowaciński Z (2001) Polska czerwona księga zwierzat. Kręgowce (Polish red data book of animals. Vertebrates). Państwowe Wydawnictwo Rolnicze i Leśne, Warszawa, p 328

Haedrich RC (1977) A sea lamprey from the deep. Copeia 1977:767-768

Halliday RG, Mott JL (1991) Marine distribution of the sea lamprey (Petromyzon marinus) in the northwest Atlantic. Can J Fish Aquat Sci 48:832-842

Hardisty MW (1986) A general introduction to lampreys. In: Holcik J (ed) The freshwater fishes of Europe. Band 1/1 Petromyzontiformes. Aula Verlag, Wiesbaden

HELCOM (2007) HELCOM Red list of threatened and declining species of lampreys and fish of the Baltic Sea. Balt Sea Environ Proc 109:1-40

Hubbs CL, Potter IC (1971) Distribution, phylogeny and taxonomy. In: Hardisty MW, Potter IC (eds) The biology of lampreys, Vol 1. Academic Press, London

Hunn JB, Youngs WD (1980) Role of physical barriers in the control of sea lamprey (Petromyzon marinus). Can J Fish Aquat Sci 37:2118-2122

Igoe F, Quigley DTG, Marnell F, Meskell E, O'Connor W, Byrne C (2004) The sea lamprey Petromyzon marinus (L.), river lamprey Lampetra fluviatilis (L.) and brook lamprey Lampetra planeri (Bloch) in Ireland: general biology, ecology, distribution and status with recommendations for conservation, biology and environment. Biol Environ Proc R Ir Acad B 104:43-56

Imam AKES, Lühmann M, Mann H (1958) Über Neunaugen und Neunaugenfischerei in der Elbe. Fischwirt 9:249-261

Kainua K, Valtonen T (1980) Distribution and abundance of European river lamprey (Lampetra fluviatilis) larvae in 3 rivers running into Bothnian Bay, Finland. Can J Fish Aquat Sci 37:1960-1966

Kelly FL, King JJ (2001) A review of the ecology and distribution of 3 lamprey species, Lampetra fluviatilis (L.), Lampetra planeri (Bloch) and Petromyzon marinus (L.): a context for conservation and biodiversity considerations in Ireland. Biol Environ Proc R Ir Acad B 101:165-185

Kloppmann MHF, Böttcher U, Damm U, Ehrich S, Mieske B, Schultz N, Zumholz K (2003) Erfassung von FFH-Anhang II-Fischarten in der deutschen AWZ von Nord- und Ostsee. Final report for the German Federal Agency of Nature Conservation, p 82, available at http://habitatmare.de/de/ downloads/berichte/Erfassung_FFH_Fischarten_Nord_u_ Ostsee_2003.pdf

Korte E (1999) Bestandsentwicklung der Fischarten der hessischen Rheinaue 1994-1997. Reproduktionsstrategien, Jungfischaufkommen, Gefährdung, Entwicklungstendenzen. Umweltplanung, Arbeits- und Umweltschutz 268: $1-186$
Kottelat M, Freyhof J (2007) Handbook of European freshwater fishes. Kottelat, Cornol, and Freyhof, Berlin, p 646

Krappe M (2004) Quantitative Analysen populationsbiologischer Phänomene im Lebenszyklus des Bachneunauges Lampetra planeri (Bloch, 1784). PhD dissertation, University of Rostock, p 241

Kull T (1999) Estonian biodiversity strategy and action plan. EPMÜ Keskkonnakaitse Instituut, Tallinn-Tartu, p 165

Lehtonen H (2006) Actions taken to protect and restore the river lamprey in Finland. In: ICES (2006) Migratory fish: how land managers and fishing associations contribute to the protection of their habitats. Baltic Area Conf, 22 Jun 2006, Copenhagen, available at www.fdd.fr/eufish/baltic_ conference.php

Leipe T, Königstedt D (1988) Zum Vorkommen und Schutz der Neunaugen (Cyclostomata, Petromyzontiformes) in Mecklenburg. Naturschutzarb Mecklenbg-Vorpomm 31: $12-21$

Lelek A (1973) Occurrence of the sea lamprey in midwater off Europe. Copeia 1973:136-137

Lelek A (1987) Threatened fishes of Europe. In: Holcik J (ed) The freshwater fishes of Europe, Vol 9. Aula Verlag, Wiesbaden, p 343

Ljunggren N (2006) Lampreys in Swedish waters, the situation of sea and river lamprey. In: ICES (2006) Migratory fish: how land managers and fishing associations contribute to the protection of their habitats. Baltic Area Conf, 22 Jun 2006, Copenhagen, available at www.fdd.fr/eufish/ baltic_conference.php

Maitland PS (1980) Review of the ecology of lampreys in northern Europe. Can J Fish Aquat Sci 37:1944-1952

Maitland PS (2003) Ecology of the river, brook and sea lamprey-Lampetra fluviatilis, Lampetra planeri and Petromyzon marinus. Conserving Natura 2000 Rivers. Ecol Ser 5:1-52

Maitland PS, Campbell RN (1992) Freshwater fishes. Harper and Collins, London

Mäkelä H, Kokko H (1990) 'Nahkiaiskantojen hoito', Vesi ja ymparistohallituksen monistesarja 208. Vesi ja ymparistohallitus, Helsinki, p 100

Meyer L, Brunken H (1997) Historical occurrence and current distribution of migrating fishes and lampreys (Osteichthyes: Cyclostomata) in the drainage system of the River Aller (Lower Saxony) with an evaluation of future developments of their stocks. Braunschw Naturkdl Schr 5: 281-303 (in German)

Möller H (1984) Daten zur Biologie der Elbfische. Verlag Heino Möller, Kiel

Ojutkangas E, Aronen K, Laukkanen E (1995) Distribution and abundance of river lamprey (Lampetra fluviatilis) ammocoetes in the regulated river Perhonjoki. Regul Rivers Res Manag 10:239-245

Petersen B, Ellwanger G, Bless R, Boye P, Schröder E, Ssymank A (2004) Das europäische Schutzgebietssystem Natura 2000. Ökologie und Verbreitung von Arten der FFH-Richtlinie in Deutschland. Schriftenr Landschaftspfl Natursch 69:693

Potter IC (1980) The Petromyzontiformes with particular reference to paired species. Can J Fish Aquat Sci 37: 1595-1615

Raczyński M, Filipiak J (1999) A preliminary biological and morphometric characteristics of river lamprey (Lampetra fluviatilis (L.)) from Lake Dabie. Electron J Pol Agric Univ Fish 2, p 12

Reshetnikov YS (2003) Atlas of Russian freshwater fishes, Vol 1. Nauka, Moscow, p 378 
Saat T (2003) Sea lamprey. In: Ojaveer E, Pihu E, Saat T (eds) Fishes of Estonia. Estonian Academy Publishers, Tallinn, p 47-48

Saat T, Järvekülg R, Eschbaum R (2000) The status of threatened freshwater fish species in Estonia. Int Symp Freshwater Fish Conserv: Options for the Future. 30 Oct - 5 Nov 2000, Albufeira, Portugal, p 24

Salewski V (2003) Satellite species in lampreys: a worldwide trend for ecological speciation in sympatry? J Fish Biol 63: 267-279

Schreiber A, Engelhorn R (1998) Population genetics of a cyclostome species pair, river lamprey (Lampetra fluviatilis L.) and brook lamprey (Lampetra planeri Bloch). J Zool Syst Evol Res 36:85-/99

Schröder H (1995) Meerneunaugen in den Küstengewässern Mecklenburg-Vorpommerns. Meer Museum 11: $31-40$

Sjölander E (1997) Flodnejonöga - Lampetra fluviatilis Linnaeus 1758. Fisk- \& Vattenvård i Norrland $A B$, Fagervik

Spratte S (2004) Projektierungsstudie zur Verbesserung der Bestandsentwicklung von Neunaugen in SchleswigHolstein. Landessportfischerverband Schleswig-Holstein e.V., Kiel, p 36

Spratte S, Hartmann U (1998) Süßwasserfische und Neunaugen in Schleswig-Holstein. Ministerium für ländliche Räume, Landwirtschaft, Ernährung und Tourismus des Landes Schleswig-Holstein, Kiel

Sterner E (1918) Die niederelbische Küstenfischerei, II. Die Fischereiarten. 10. Die übrigen Fischereiarten im oberen Teil. Fischerbote 10:245-253

Thiel R, Salewski V (2003) Verteilung und Wanderung von Neunaugen im Elbeästuar (Deutschland). Limnologica 33: 214-226

Thiel R, Winkler HM, Neumann R (2004) Erfassung von FFHAnhang II Fischarten in der deutschen AWZ von Nordund Ostsee. Study for the German Federal Agency of Nature Conservation. German Oceanographic Museum, Stralsund. 1. Report 02/2004, p 67

Editorial responsibility: Cornelius Hammer, Rostock, Germany
Thiel R, Winkler HM, Riel P, Neumann R (2005) Survey of river and sea lampreys in German waters of the Baltic Sea - basis of successful rebuilding programmes. ICES CM 2005/W:06, p 33

Thiel R, Winkler HM, Neumann R (2007) Erfassung von FFH-Anhang II-Fischarten in der deutschen AWZ von Nord- und Ostsee. Final report for the German Federal Agency of Nature Conservation, available at www.bfn. de/habitatmare/de/downloads/berichte/Erfassung_FFH_ Fischarten_Nordsee-Ostsee_2007.pdf

Tuunainen P, Ikonen E, Auvinen H (1980) Lampreys and lamprey fisheries in Finland. Can J Fish Aquat Sci 37: 1953-1959

- Valtonen T (1980) European river lamprey (Lampetra fluviatilis). Fishing and lamprey populations in some rivers running into Bothnian Bay, Finland. Can J Fish Aquat Sci 37:1967-1973

Waterstraat A, Krappe M (2000) Beiträge zur Ökologie und Verbreitung von FFH-Fischarten und Rundmäulern in Mecklenburg-Vorpommern. 1. Das Flussneunauge (Lampetra fluviatilis L.) im Peenesystem. Natur Naturschutz Mecklenbg-Vorpomm 35:64-79

Wilkens H, Köhler A (1977) Die Fischfauna der mittleren und unteren Elbe: die genutzten Arten. Abh Natwiss Ver Hambg 20:185-222

Winkler HM, Spieß HJ, Waterstraat A, Krappe M, Lemcke R (1999) Monitoring von FFH-Arten von Rundmäulern und Fischen in Referenzgebieten. Naturschutzarb MecklenbgVorpommern 42:24-40

Winkler HM, Skóra K, Repečka R, Ploks M and others (2000) Checklist and status of fish species in the Baltic Sea. ICES CM 2000/Mini 11, p 15

Winkler HM, Waterstraat A, Hamann N (2002) Rote Liste der Rundmäuler, Süßwasser- und Wanderfische Mecklenburg-Vorpommerns, kommentiert, Stand 2002. Umweltministerium Mecklenburg-Vorpommern, Schwerin, p 52

Witkowski A (1991) Threats and protection of freshwater fishes in Poland. Neth J Zool 42:243-259

Submitted: July 20, 2008; Accepted: July 17, 2009

Proofs received from author(s): September 28, 2009 